\title{
USES OF HUMOR TO TEACH MATHEMATICS: A DIDACTIC PROPOSAL
}

\author{
Luís Menezes \\ Instituto Politécnico de Viseu (PORTUGAL)
}

\begin{abstract}
The Didactics of Mathematics, as a scientific field, seeks to find the most effective teaching methods. In recent years, the inquiry-based mathematics teaching has established as an approach to productive teaching, especially when compared to the transmissive approach. In inquiry-based mathematics teaching, challenging mathematical tasks are an essential element as they serve as a starting point for learning. The humor for instructional purposes has also been affirmed as a possibility to enrich the teaching of Mathematics, performing affective and cognitive functions. In the study presented here, we are developing and applying mathematical tasks with a humorous nature that can fit into inquiry-based mathematics teaching. The first results show good involvement from the students (grades 4 and 5) and the availability of teachers to use this type of tasks.
\end{abstract}

Keywords: Instructional humor, Inquiry-based mathematics teaching, Mathematical tasks.

\section{INTRODUCTION}

This paper is part of an ongoing research project, called HUMAT - Humor in Mathematics Teaching, which aims: (i) to describe primary teachers' knowledge and practices about humor in teaching mathematics; (ii) to study the knowledge and practices of primary teachers, who use in a systematic way humor to teach mathematics. To achieve the second objective, the project team is developing didactic resources, in the form of mathematical tasks, which are used in an inquiry mathematics teaching perspective. This didactic proposal, from which we present here some mathematical tasks, is based on two assumptions: 1 . The involvement and exploitation of challenging and meaningful mathematical tasks by students is a good way for a powerful mathematical learning; 2 . Humor is a very relevant social fact that can be used to teach mathematics, with affective and cognitive purposes. So, next, I begin by discussing the concept of inquiry-based mathematics teaching and the role that mathematical tasks play in it. Then, I discuss the concept of humor and analyze its educational value.

\section{THEORETICAL FOUNDATION}

\subsection{Inquiry-based mathematics teaching}

In inquiry-based mathematics teaching approach, students' mathematics learning is based on their involvement in rich mathematical tasks, like explorations, investigations or problems, using their previous knowledge and experience as a starting point (Menezes, Oliveira \& Canavero, 2015; Ponte,2005). This approach to teaching is in opposition to the transmission model, in which students are attentive listeners of teacher's explanations, followed by tasks of applying knowledge, usually, exercises (Guerreiro, Tomás Ferreira, Menezes \& Martinho, 2015; Ponte,2005).

There are different possibilities for structuring lessons in an inquiry-based approach. However, usually, an inquiry-based lesson is structured in three phases: the "launch phase", the "explore phase" and the "discuss and summarize phase" (Stein, Engle, Smith \& Hughes, 2008). Some authors consider four phases, unfolding the last one in two: (i) Orchestrating the discussion; and (ii) Systematizing mathematical learning (Menezes, Oliveira \& Canavero, 2015).

The inquiry-based mathematics teaching approach requires from the teacher the selection of a challenging task because it creates conditions for the mathematics learning. In the first phase of the lesson (the launching of the task), the teacher's main role is to present the mathematical task to the class to guarantee the appropriation of the task by the students and to promote students' adhesion to the task. In the exploration of the task, the teacher accompanies students' autonomous work in solving the task. The teacher's role is to guarantee the development of the task by the students and to keep the cognitive challenge. In the next phase (discussion), the teacher intends to promote the mathematical quality of the presentations and to promote interactions among students in the 
discussion of mathematical ideas. In the last phase (systematizing mathematical learning), the teacher aspires to institutionalize concepts or procedures on mathematical topics, to institutionalize ideas or procedures concerning the development of transversal capabilities and to establish connections with prior learning (Menezes, Oliveira \& Canavero, 2015).

\subsection{Humor and its educational value}

The concept of humor has been studied since classical antiquity, having several points of view on it. Despite this, Banas, Dunbar, Rodriguez e Liu (2011) considers that "there is widespread agreement among scholars that humor involves the communication of multiple, incongruous meanings that are amusing in some manner" (p. 117). The incongruity theory is one that seeks to explain the functioning of the humor. These theories defend that a surprise or contradiction is indispensable for humor, and "people understand humorous communication because they are able to resolve the incongruity. With incongruity theory, there is an emphasis on cognition (Banas et al, 2011).

Humor is much appreciated in society, being very present in many professional fields. Is he presenting at school? Martin (2007) states that "evidence from several studies indicates that many teachers tend to use humor quite frequently in classroom settings." (p. 23). Most recently, results from a study conducted in Portugal and Spain, with more than 1000 teachers, show that about $80 \%$ of Mathematics teachers, of all levels of teaching, say they regularly use humor to teach mathematics (Flores, Menezes, Ribeiro \& Viseu, 2017; Menezes, Viseu, Ribeiro \& Flores, 2017). But, what leads teachers to use humor to teach? and, what points out research on the educational value of humor to teaching? Martin (2007) defends Instructional humor because, if appropriate, may be an effective tool to create a positive classroom environment and to facilitate teacher communication. This author underlines that research has provided "evidence that the judicious use of humor by teachers in the classroom increases students' enjoyment of learning, their perceptions of how much they learn, and how positively they feel about the course and the instructor" (p. 23). Some authors, in addition to the affective function of the humor, also point out their cognitive function, that is, humor becomes the target of the mathematical activity of students, through the performance of mathematical tasks of humorous context (Guitart \& Flores, 2003; Guitart, 2012).

\section{METHODOLOGY}

In the HUMAT research project, in which this study takes place, after studying the use of the humor by teachers for educational purposes, we are developing, applying and improving tasks with humorous mathematical content. These tasks are designed to be used in inquiry-based classes and seek to emphasize the cognitive dimension of the humor by playing with situations of incongruity.

Tasks have an open structure and they are directed to the end of primary school (grades 4 and 5). These tasks, some of which are presented below, intend to constitute a didactic proposal, being accompanied by curricular recommendations and classroom episodes. For this, we collected data in primary school classes, through audio (AC), video (VC), documentary records (DR) and interviews (I). This data is submitted to content analysis, in an attempt to understand how these tasks of a humorous nature can contribute to the learning of mathematics.

\subsection{Mathematical tasks}

We present here some of the mathematical tasks developed for the teaching of Mathematics at the end of primary education. 

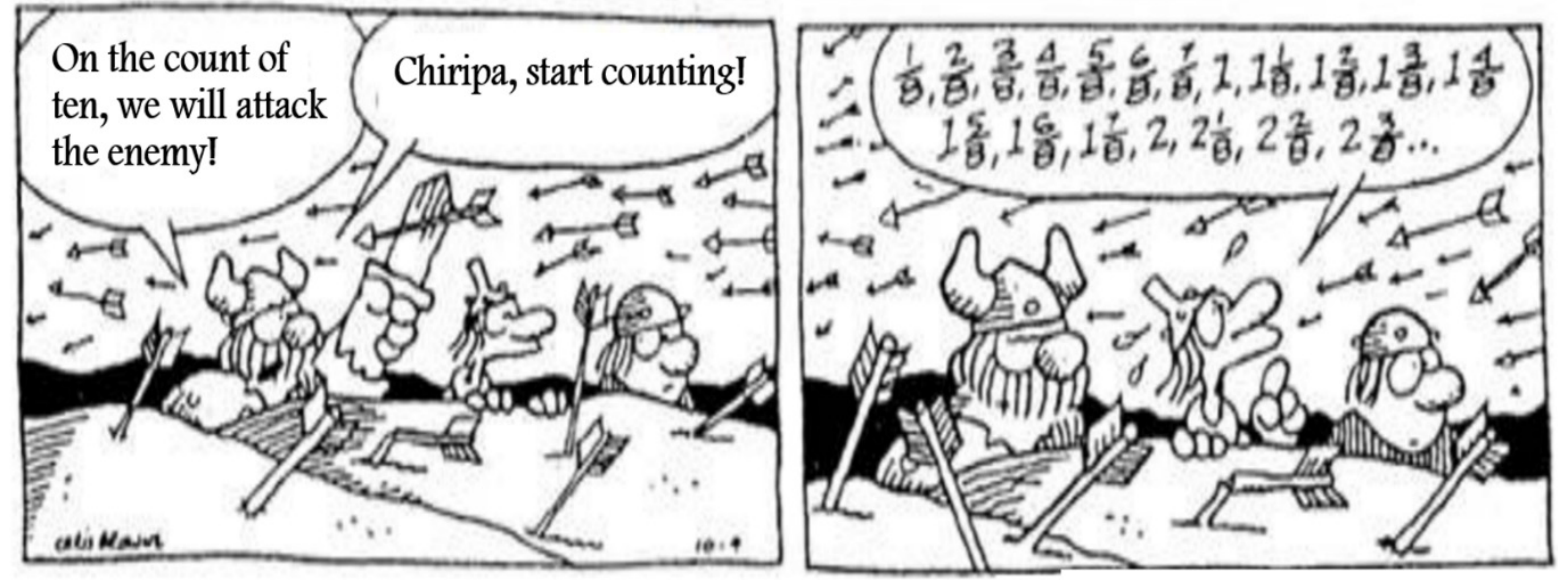

Haqar, the Terrible. Chris Browne

Figure 1. Illustration of the task "Charge!".

- Describe the situation presented in the comic strip. What could have been the protagonist's intention and what strategy did he used?

- How many numbers must Chiripa say before the attack? Which numbers were used? And which representations?

- How could he reduce the cooldown time? And what if he wanted to delay the attack?

- Imagine that Chiripa reaches $9 \frac{7}{8}$. What strategy can he use in order to further delay the attack?

Task 2. A smaller map

\section{Hagar the Horrible by Dik Browne}

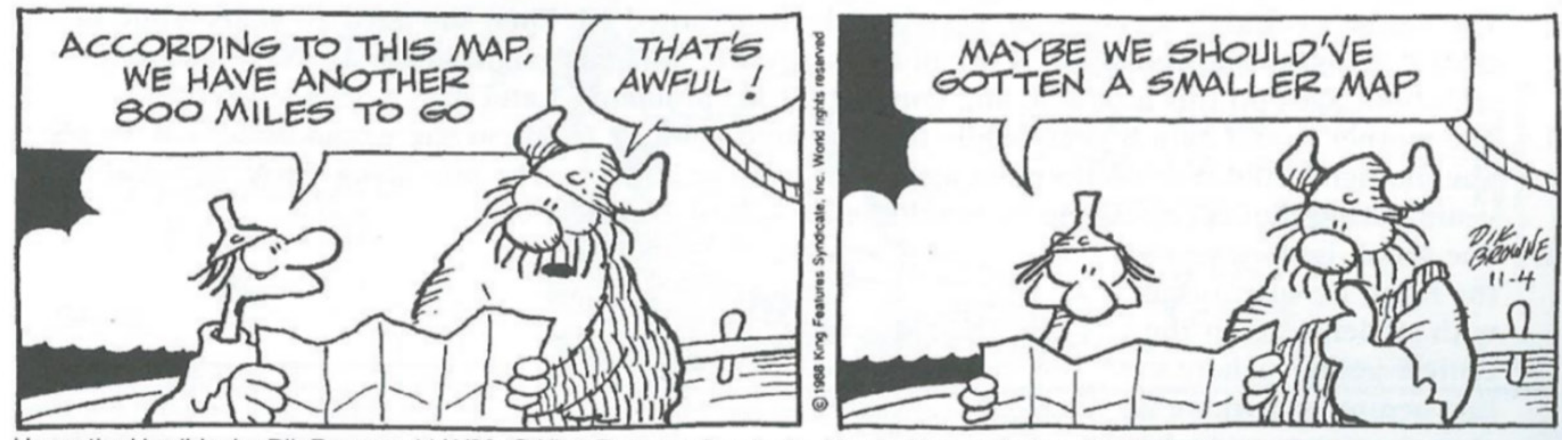

Hagar the Horrible, by Dik Browne, 11/4/98. $\odot$ King Features Syndicate. Used with permission. All Rights Reserved.

Figure 2. Illustration of the task "A smaller map".

- What do you think about Chiripa's idea? It is a good idea?

- What should Chiripa know about maps? Write a letter to Chiripa explaining how to use maps. 
Task 3. Extra touches!
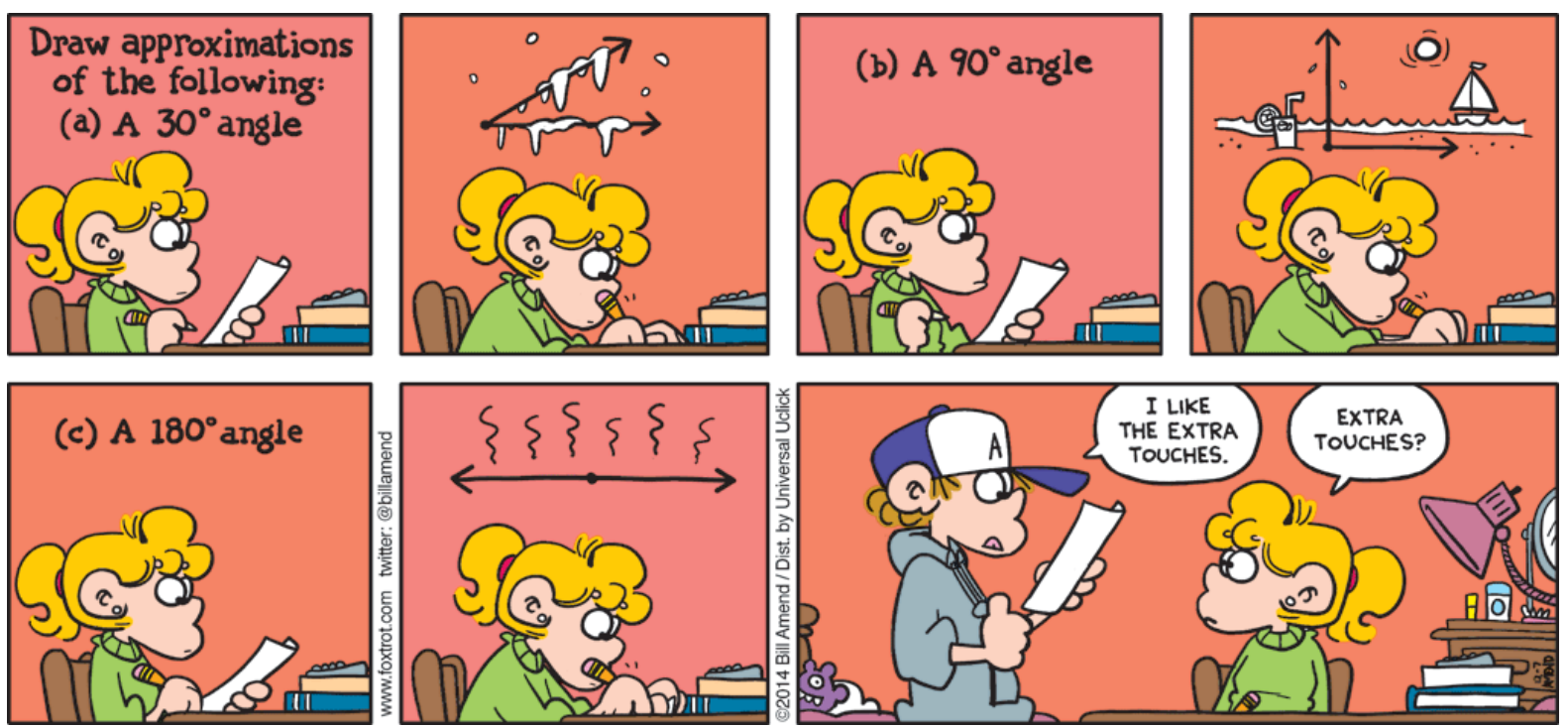

Figure 3. Illustration of the task "Extra touches!".

- Describe the situation presented in the comic strip. What could have been the protagonist's intention?

- Do you agree with the design of the angles?

- Present other examples of reality with the same angles.

Task 4. Ordering pizzas

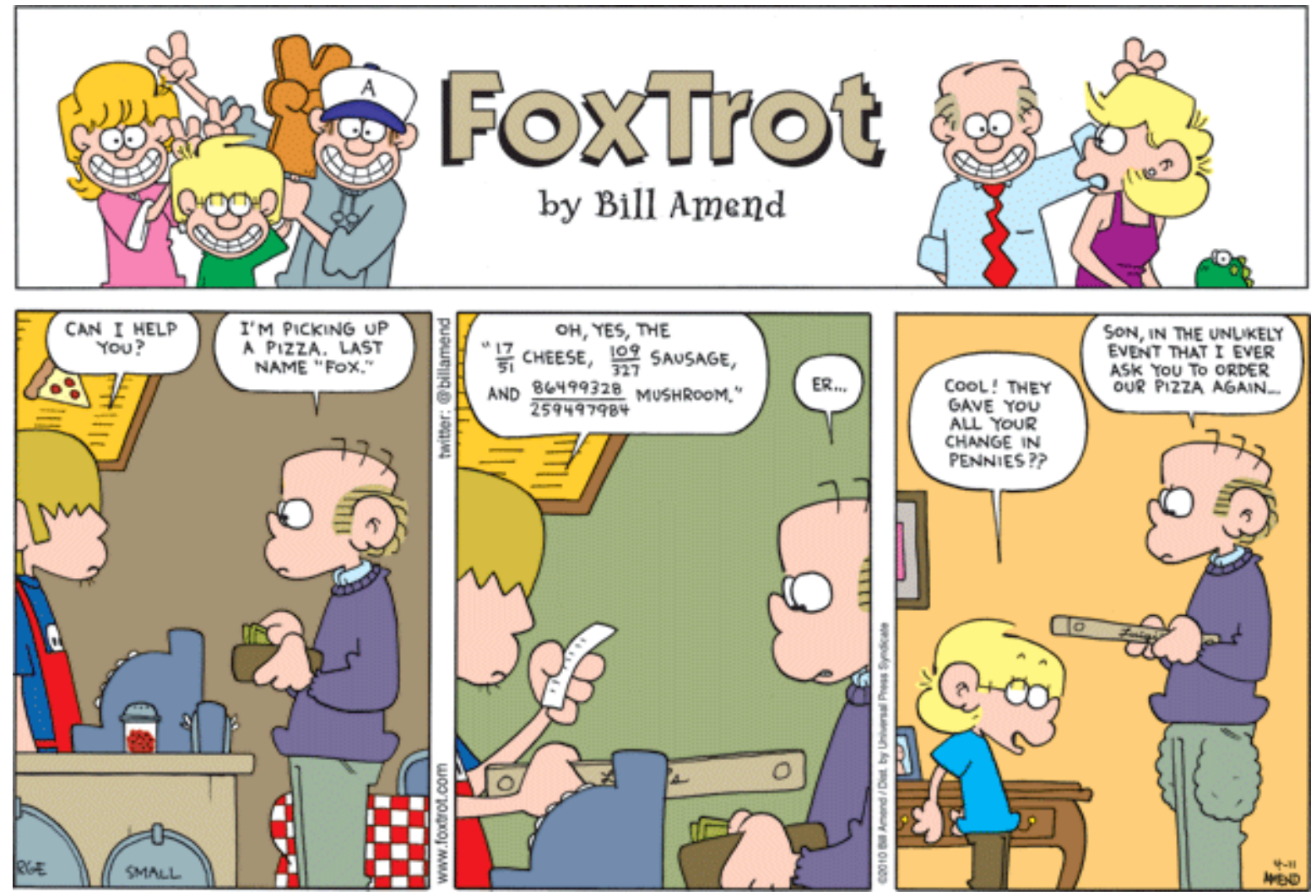

Figure 4. Illustration of the task "Ordering pizzas". 
- Describe the situation presented in the comic strip. What could have been the protagonist's intention?

- What do you think about this pizza order? How was mathematics used? Why is not this use of mathematics common?

\section{RESULTS}

In this section, I present some results of applying the task "Charge!" in a grade 5 class, with the intention of teaching rational numbers: representation and ordering. The task was included in an inquiry-based mathematics class and was developed by an experienced teacher.

As usual in this type of class, teacher begins by presenting the task and clarifying some doubts. After that, students were organized in small groups and worked autonomously. The teacher followed the work of the students, giving small support. Students solved the task on the sheet given by the teacher and prepared to the collective discussion.

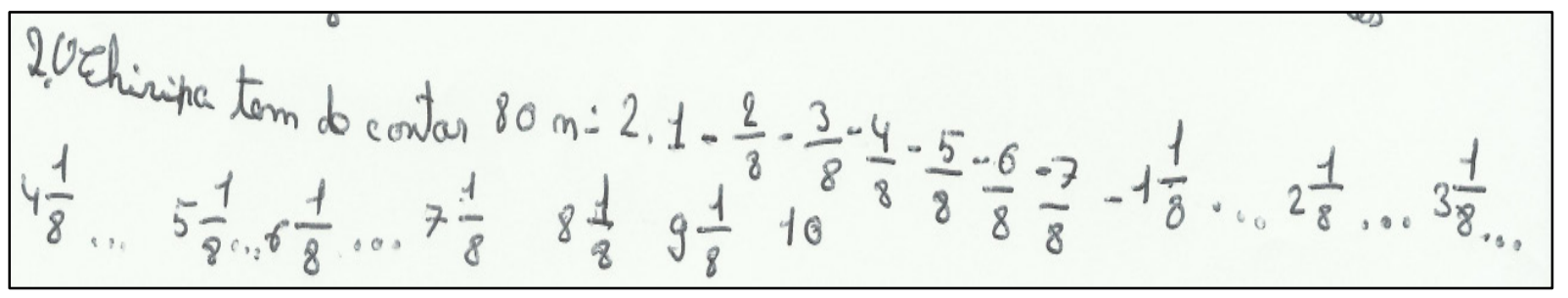

Figure 5. Resolution of the question 2. Students write "Chiripa has to count 80 numbers" (Alves_DR).

Students discuss the answer to question 1: they seek to understand the reasons for this comic count and identify the fear of the Vikings.

Student: Yes, but you have to say why he did it, he could only count normally to 10 .

Teacher: Do you agree, Leila?

Leila: Well, I did not, but we thought he wanted to delay the attack, because it took so much longer, he had to say more fractions.

Jessica: The Vikings want to attack, so the boss asks one of his soldier to count to 10 . Then, his soldier starts: $1 / 8,2 / 8,3 / 8 \ldots$ We thought he wanted to delay the attack.

Teacher: Why would he want to delay the attack, Ronaldo?

Ronaldo: Because he was afraid. They could be at a disadvantage and wanted to delay.

Teacher: Tadeu.

Tadeu: I only saw 3 Vikings and millions of arrows, they were at a disadvantage. (Alves_VC)

After understanding Chiripa's comic strategy, students advance in the mathematical understanding of the rational numbers represented in fraction form. In discussion, they understand what happens to the number as they vary the denominator of the fraction:

Teacher: And how could Chiripa reduce the waiting time? Or, if it were a little more cowardly, as the colleague said, how could he delay him?

Lili: To reduce, we think that we decrease in the denominator.

Teacher: Explain it better.

Lili: To reduce time if they got the smallest denominator, for example 3 , it was easier. They were $1 / 3,2 / 3 \ldots$

Student: Sure! So, if you counted $1 / 3$ in $1 / 3$ it was still much faster.

Teacher: And how many numbers did Chiripa have to say before attacking?

Lili: It was 3 times $10 \ldots 30$ !

Student: Why 30 ? 
Lili: So, there are 3 numbers in each unit ... $3 / 3$ is 1 , as are 10 gives 30 !

Teacher: What about this group? (Alves_VC)

This type of tasks, and the discussion it provided in class, was well received by students, who acknowledge their fun side but also their role in their learning. "I enjoyed doing them, I think they were fun and always give a more fun way to learn contents, I think it was interesting in the discussion. (...) Fun not in terms of playing with each other, (...) but in a way not normal, when we use textbooks, we are playing with numbers." (Alves_l)

\section{CONCLUSIONS}

This text shows the ongoing work at HUMAT - Humor in Mathematics Teaching to design and apply humorous mathematical tasks to teach mathematics at the end of primary education, combining the affective function of the humor with its cognitive function. By this, we propose a kind of humor, inserted in mathematical tasks, that defies the intelligence of the students and leads them to use Mathematics. Thus, as Flores and Moreno (2011) say, through this type of tasks, we think that students become mathematically competent, in particular, mathematically competent to laugh.

\section{ACKNOWLEDGEMENTS}

This work is financed by national funds through FCT - Fundação para a Ciência e Tecnologia, I.P., under the project UID/Multi/04016/2016. Furthermore we would like to thank the Instituto Politécnico de Viseu and CI\&DETS for their support.

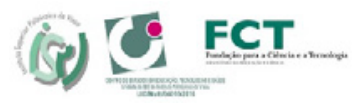

\section{REFERENCES}

[1] L. Menezes, H. Oliveira, A. P. Canavarro, "Inquiry-based mathematics teaching: The case of Célia" in Educational paths to Mathematics (U. Gellert, J. Gimenez Rodriguez, C. Hahn, S. Kafoussi, eds.), pp.305-pp.321, Cham: Springer, 2015.

[2] J. P. Ponte, "Gestão curricular em Matemática" in O professor e o desenvolvimento curricular (GTI eds.), pp.11-pp.34, Lisboa: APM, 2005.

[3] A. Guerreiro, R. Tomás Ferreira, L. Menezes, M. H. Martinho, "Comunicação na sala de aula: A perspetiva do ensino exploratório da Matemática”, Zetetiké, vol. 23, no. 4, pp. 279-295, 2015.

[4] M. K. Stein, R. A. Engle, M. S. Smith, E. K. Hughes, "Orchestrating productive mathematical discussions: Five practices for helping teachers move beyond show and tel", Mathematical Thinking and Learning, vol. 10, no. 4, pp. 313-340, 2008.

[5] J. A. Banas, N. Dunbar, D. Rodriguez, S. J. Liu, "A review of humor in educational settings Four decades of research", Communication Education, vol. 60, no. 1, pp. 115-144, 2011.

[6] R. Martin, The Psychology of Humor - An Integrative Approach. London: Elsevier Academic Press, 2007.

[7] P. Flores, L. Menezes, A. Ribeiro, F. Viseu, " Empleo del humor de profesores españoles y portugueses en la enseñanza de las Matemáticas", Atas del Congresso Ibero Americano de Educación Matemática, in press, 2017.

[8] L. Menezes, F. Viseu, A. Ribeiro, P. Flores, "O humor nas práticas letivas dos professores que ensinam Matemática" in Seminário de Investigação em Educação Matemática (L. Menezes, A. Ribeiro, H. Gomes, A. P. Martins, F. Tavares, H. Pinto eds.), pp.51-pp.67, Viseu: APM, 2017.

[9] M. Guitart, P. Flores, "O Humor gráfico para la enseñanza y el aprendizaje del azar", Suma, no. 42, pp. 81-89, 2003.

[10] M. Guitart, Permitido reír... Estamos en clase El humor como recurso didáctico en aula de Estadística. Mendoza: Universidade Nacional de Cuyo, 2012.

[11] P. Flores, A.J. C Moreno, Matemáticamente competentes para reír. Barcelona: Graó. 